\title{
Comparative epidemiology of multiple sclerosis and dental caries
}

\author{
WILLIAM CRAELIUS \\ From the Department of Biological Sciences, Stanford University, California and the Department of Biology, \\ Lafayette College, Pennsylvania
}

SUMMARY The geographical distribution and other epidemiological characteristics of multiple sclerosis (MS) are compared with those of dental caries. The rates of death due to MS in Australian states are linearly related to the numbers of decayed, missing, and filled (DMF) teeth found in individuals from those states $(r=0.97, P<0.002)$. In the United States of America, a strong positive correlation $(r=0.55, P<0.001)$ also exists between $M S$ death rates and dental caries indices. The prevalence of MS in 45 countries or areas correlates well with the frequencies of DMF teeth among children of school age in those locations $(r=0.78, P<0.001)$. The prevalence of MS also correlates well with the percentage of edentulous individuals in certain countries $(r=0.99$, $\mathrm{P}<0.001)$. A review of the literature shows that the risk for dental caries is lower among the following groups: the lower socioeconomic classes in the United States of America; Chinese immigrants to England compared with natives; blacks compared with whites; and males compared with females. The dental caries risk is higher during pregnancy and lactation. All these trends have been described for MS as well. It is suggested that dental caries may be a more accurate epidemiological model for MS than poliomyelitis. It is also suggested that MS and dental caries may share certain aetiological factors, two of which may be dietary excess of certain fats, and vitamin D deficiency.

The incidence of multiple sclerosis (MS) is lowest in the sunnier areas of the world and, with a few important exceptions, increases as the annual amount of sunshine declines. The annual amount of sunshine received by an area has the highest (negative) correlation with MS rates of any variable studied (Leibowitz et al., 1967). The world's highest prevalence of MS cases occurs in the Shetland and Orkney Islands (Poskanzer et al., 1976), which are among the least sunny regions (Landsberg $e t$ al., 1965). At the other extreme, MS is virtually unknown in the tropics, and numerous studies and reviews have documented that living in sunny climates, especially during the very early years of life (Leibowitz et al., 1973; Visscher et al., 1977), offers one protection against acquiring MS (Limburg, 1950; Acheson et al., 1960; Kurland and Reed, 1964; Goldberg, 1974). Certain populations, however, like the Eskimos, appear to be protected against acquiring MS in spite of their extremely low sunlight exposures; the Japanese also are protected without the benefit of tropical levels of sunlight (Alter, 1977).
These exceptional populations present an unexplained paradox in the otherwise close relationship between MS and lack of sunlight. One explanation offered states that both very high and very low levels of sunlight may protect against MS, but that there is an 'optimally detrimental' amount of sunshine which is responsible for MS (Alter, 1977). A simpler explanation can be found by considering other diseases with geographical variations similar to those of MS. One example is rickets, which has a peculiar geographical distribution explained more than 50 years ago (Mellanby, 1921).

At about the turn of the century, rickets was a common childhood affliction in temperate climates, both north and south of the equator, and usually increased with latitude (Hess, 1929). Although little quantitative data are available, the geographical nature of rickets was summarised by Hess, who stated that 'a map of the incidence of rickets is the practical equivalent of a map of deficiency of sunlight'. Certain exceptional populations were noted, however, such as the Japanese and the 
Eskimos of northern Greenland, who, in spite of their northern locations, did not get the disease. A physician who practised extensively in Japan (Palm, 1890) was 'struck with the absence of rickets amongst the Japanese', and observed that 'the staple food of the people is rice and fish'. Knowing the anti-rachitic property of fish oils, we can now recognise, with hindsight, that Palm's naive dietary observation is the probable key to the paradoxical epidemiology of rickets. The relationship between sunlight, vitamin $\mathrm{D}$, and fish oils is now firmly established, and epidemic rickets is a thing of the past.

The geographical similarity between rickets and MS which can be seen at the qualitative level cannot be fully explored because current data on rickets are inadequate. Qualitative comparison of MS with a more recent disease, paralytic poliomyelitis, has been made (Poskanzer et al., 1963), in spite of serious geographical discrepancies between the diseases. Polio was epidemic in many parts of the tropics (Leibowitz and Alter, 1973), and also among the Eskimos (Rhodes, 1949). Nevertheless, the polio analogy is cited as evidence for the viral origin of MS (Kurtzke, 1977), and has inspired many unsuccessful searches for the 'MS virus' (Johnson, 1975; Carp et al., 1977; Symington and Mackay, 1978). A more recent comparative epidemiological survey was undertaken by Wolfgram (1975) in which the World Health Organisation (WHO) mortality statistics were systematically searched to discover whether any diseases showed parallel geographical distributions with MS. Among approximately 83 diseases listed for 36 countries, Wolfgram found one, cancer of the colon, which had a significantly positive correlation with MS. The epidemiological similarities between MS and cancer of the colon led the author to propose that the diseases were possibly caused by some related dietary factors. A more recent survey (Knox, 1977) has supported the epidemiological link between cancer of the colon and MS.

Dental caries has been recently added to the WHO compilation and this disease is here reported to share many epidemiological features in common with MS. Casual comparison of the WHO map of dental caries incidence throughout the world (Barmes and Infirri, 1977) reveals a striking parallel in general trend. The dependence on latitude of the incidence of dental caries led many investigators to theorise that caries attack rates increased with decreasing levels of sunlight, and that sunlight provided protection against caries (Mills, 1937; East, 1939; Blackberry, 1943; Saunders, 1945; Dunning, 1953; Shaw, 1970). The sunshine hypothesis, similarly proposed for both dental caries and MS, has not been experimentally tested for either disease, in spite of an abundance of epidemiological evidence pointing to sunshine as a possible protecting agent.

Dental examinations of 51 MS patients (Firnhaber and Orth, 1977) have demonstrated an abnormally high rate of carious teeth among them, compared with an age-matched group of epileptics. This result certainly does not prove any aetiological relationships between MS and caries, but it does give a further rationale for the present epidemiological study of the two diseases.

\section{Material and methods}

Geographical comparisons of MS and dental caries were made in three areas: Australian states, the United States of America, and the world. Australian dental data (Table 1) were taken from a study (Andrews, 1948) of 2000 men and women in

Table 1 Dental caries and death rates for multiple sclerosis in Australian states

\begin{tabular}{llll}
\hline State & $\begin{array}{l}M S \\
\text { death rate }\end{array}$ & DMF teeth $\dagger$ & $\begin{array}{l}\text { Dentists per } \\
\text { 1000 population }\end{array}$ \\
\hline Western Australia & 0.37 & 17.50 & 4.4 \\
New South Wales & 0.65 & 18.66 & $5 \cdot 3$ \\
South Australia & 0.67 & 18.57 & 3.7 \\
Queensland & 0.76 & 19.72 & 4.6 \\
Victoria & 0.96 & 19.74 & 4.5 \\
Tasmania & 1.25 & 21.98 & 2.9 \\
\hline
\end{tabular}

$r=0.97 \mathrm{P}<0.002$ (MS and DMF)

$r=-0.59 \mathrm{P}>0.1$ (MS and Dentists)

$r=-0.61 \mathrm{P}>0.1$ (DMF and Dentists)

* Average age-adjusted death rate for 1950-59 (Acheson, 1961)

+Decayed, missing and filled teeth among RAF personnel drawn from †Decayed, missing and filled teeth among RAF per

the designated state $1939-45$ (Andrews, 1948)
$\ddagger$ Number of dentists per 1000 population, from the 1933 Australian Census

the Royal Australian Air Force, drawn from various states. The data are presented in terms of the average numbers of decayed, missing, and filled (DMF) teeth during the period 1939-1945. MS death rates for the corresponding states were taken from Acheson (1961). These are age-adjusted death rates compiled by the Department of Medical Statistics from 1950 to 1959. Both the dental and the MS data are based on Caucasians only. Because there is a gap of five to 20 years between the dental surveys and the MS data, the validity of the comparison between the two sets of data must be considered. Statistical comparison could be made most directly if the dental health statistics were known for the same population on which the MS death rates are based. However, the fact that the dental surveys precede the MS deaths by five to 20 years means that both samples were taken from roughly the same generation, since the average age of death from MS is 52 years (Leibowitz and Alter, 1973), and the age 
of subjects in the dental surveys ranged from 18 to 35 years. Thus, although the sampling is separated in time, the population studied is roughly the same in both surveys. Dental data from older adults would in fact be less valid methodologically because the DMF figure becomes a less reliable index of dental caries with increasing age (McPhail, 1967). The use of war time dental data for the various Australian states poses no special problem. The caries rate among most European children declined during the second world war, concurrently with a decline in consumption of sugar and meat; but in Australia, sugar consumption per caput did not decline, and meat consumption dropped only slightly (Official Yearbook, 1946-47). There is no reason to believe that factors associated with the war would have affected the states differentially.

Table $2 M S$ ranks and dental caries for the United States of America

\begin{tabular}{|c|c|c|c|}
\hline State & $\begin{array}{l}\text { Average } M S^{*} \\
\text { death rate } \\
1946-67\end{array}$ & MS rank & $\begin{array}{l}\text { Average } \dagger \\
\text { dental } \\
\text { rank }\end{array}$ \\
\hline $\begin{array}{l}\text { Alabama } \\
\text { Arizona } \\
\text { Arkansas } \\
\text { California } \\
\text { Colorado } \\
\text { Connecticut } \\
\text { Delaware } \\
\text { Florida } \\
\text { Georgia } \\
\text { Idaho } \\
\text { Illinois } \\
\text { Indiana } \\
\text { Iowa } \\
\text { Kansas } \\
\text { Kentucky } \\
\text { Louisiana } \\
\text { Maine } \\
\text { Maryland } \\
\text { Massachusetts } \\
\text { Michigan } \\
\text { Minneapolis } \\
\text { Mississippi } \\
\text { Missouri } \\
\text { Montana } \\
\text { Nebraska } \\
\text { Nevada } \\
\text { New Hampshire } \\
\text { New Jersey } \\
\text { New Mexico } \\
\text { New York } \\
\text { North Carolina } \\
\text { North Dakota } \\
\text { Ohio } \\
\text { Oklahoma } \\
\text { Oregon } \\
\text { Pennsylvania } \\
\text { Rhode Island } \\
\text { South Carolina } \\
\text { South Dakota } \\
\text { Tennessee } \\
\text { Texas } \\
\text { Utah } \\
\text { Vermont } \\
\text { Virginia } \\
\text { Washington } \\
\text { West Virginia } \\
\text { Wisconsin } \\
\text { Wyoming } \\
\text { Wying }\end{array}$ & 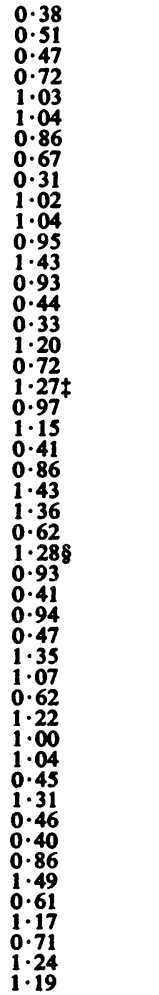 & $\begin{array}{l}3 \\
12 \\
10 \cdot 5 \\
18 \cdot 5 \\
29 \\
31 \\
20 \\
16 \\
1 \\
28 \\
31 \\
26 \\
46 \cdot 5 \\
23 \cdot 5 \\
7 \\
2 \\
38 \\
18 \cdot 5 \\
41 \\
27 \\
35 \\
5 \cdot 5 \\
21 \cdot 5 \\
46 \cdot 5 \\
45 \\
14 \cdot 5 \\
42 \\
23 \cdot 5 \\
5 \cdot 5 \\
25 \\
10 \cdot 5 \\
44 \\
34 \\
14 \cdot 5 \\
39 \\
33 \\
31 \\
8 \\
43 \\
9 \\
4 \\
21 \cdot 5 \\
48 \\
13 \\
36 \\
17 \\
40 \\
37 \\
37\end{array}$ & $\begin{array}{r}14 \\
15 \\
2 \\
19 \\
15 \\
41 \\
42 \\
17 \\
19 \\
28 \\
30 \\
19 \\
16 \\
6 \\
16 \\
21 \\
44 \\
34 \\
44 \\
34 \\
30 \\
11 \\
17 \\
23 \\
18 \\
16 \\
43 \\
43 \\
11 \\
44 \\
15 \\
28 \\
34 \\
7 \\
35 \\
39 \\
45 \\
18 \\
23 \\
10 \\
5 \\
24 \\
41 \\
17 \\
31 \\
25 \\
31 \\
12\end{array}$ \\
\hline
\end{tabular}

The numbers of dentists per 1000 population for the various states were obtained from the 1933 Australian census.

Dental health ranks for the United States of America (Table 2) were published by Dunning (1953) and are based on dental examinations of 994205 young men from three military studies in 1918, 1934, and 1943. The 1918 study (Britten and Perrot, 1941) and the 1943 study (Nizel and Bibby, 1944) were based solely on the numbers of decayed and missing (DM) teeth per person. The 1934 study (Ferguson, 1935) reported the DMF figure. Dunning (1953) averaged the results of the three studies by assigning a rank to each state within each study based on its relative dental status. MS death rates for the United States of America were taken from maps published in Leibowitz and Alter (1973) for the years 1946, 1959-61, 1958-67, and 1967. A weighted average death rate was computed from these data by applying weighting factors of 3 to the 1949-51 rates, and 10 to the 1958-67 rates, and then taking the average of all four maps. The states were ranked according to the average, with the rank 1 assigned to the state with the lowest death rate. The dental surveys precede the MS death surveys by three to 49 years, with an average time separation of 17 years. It can be assumed that, like the Australian study, the US dental surveys were carried out among roughly the same generation as the MS death surveys.

World maps of dental caries are published by McPhail and Grainger (1969) and the WHO (Barmes and Infirri, 1977). To help in the transcription of data from the study by McPhail and Grainger, the original large map $(90 \times 60 \mathrm{~cm})$ was used. The WHO map is colour coded and easy to transcribe. These studies are based primarily on dental records of children of school age using the DMF tooth count index. The dental surveys were carried out from 1940 to 1974. In both studies, countries or geographical areas were divided into five numerically equal groups representing very low, low, medium, high, and very high rates of caries. A scale of one to five was assigned to these categories. Because of the similarity in methods and criteria in these two studies, the data could be combined in order to categorise a larger number of countries. The overlapping data from the two studies usually agreed, or differed by one rank, in which case the ranks were averaged. MS prevalence data for the various countries were obtained from data presented in Leibowitz and Alter (1973), except for the prevalences in Netherlands Antilles and Senegal, taken from Kurtzke (1975), and the datum on south-east Finland, taken from Wikstrom and Palo (1975). 
The prevalences in Tables 6.1 and 7.2 of Leibowitz and Alter (1973) were averaged for each country to provide the most reliable figure. Most of the MS data represent the 1960 s, although some surveys date from the 1950s and 1970s. The countries were listed according to increasing prevalence, the list was divided into five numerically equal groups, and each group was assigned a category from one to five (Table 3).

Table 3 World MS prevalence and dental caries

\begin{tabular}{|c|c|c|c|}
\hline Area & $\begin{array}{l}\text { MS } \\
\text { prevalence }\end{array}$ & $\begin{array}{l}\text { MS } \\
\text { category }\end{array}$ & $\begin{array}{l}\text { Dental } \dagger \\
\text { category }\end{array}$ \\
\hline $\begin{array}{l}\text { Ethiopia } \\
\text { Jamaica } \\
\text { Senegal } \\
\text { Korea } \\
\text { India } \\
\text { Japan } \\
\text { Netherlands Antilles } \\
\text { Iraq } \\
\text { Turkey } \\
\text { Egypt } \\
\text { Morocco } \\
\text { Iran } \\
\text { Bulgaria } \\
\text { Israel } \\
\text { Yugoslavia } \\
\text { Italy } \\
\text { Australia } \\
\text { Greece } \\
\text { New Zealand } \\
\text { Ukraine } \\
\text { White Russia } \\
\text { France } \\
\text { Russia } \\
\text { SE Finland } \\
\text { Lithuania } \\
\text { Hungary } \\
\text { Poland } \\
\text { United States } \\
\text { Romania } \\
\text { Canada } \\
\text { Netherlands } \\
\text { Norway } \\
\text { England } \\
\text { Austria } \\
\text { Iceland } \\
\text { Faroe Is. } \\
\text { Sweden } \\
\text { Czechoslovakia } \\
\text { Switzerland } \\
\text { Denmark } \\
\text { Germany } \\
\text { Scotland } \\
\text { N. Ireland } \\
\text { Orkney Is. } \\
\text { Shetland Is. } \\
\text { Tula }\end{array}$ & $\begin{array}{l}0 \\
0 \cdot 4 \\
1 \\
2 \\
2 \\
2 \\
3 \\
3 \cdot 5 \\
4 \cdot 5 \\
6 \\
6 \\
7 \\
7 \cdot 5 \\
9 \cdot 5 \\
11 \\
15 \\
18 \\
18 \\
23 \\
23 \\
25 \\
30 \\
30 \\
32 \\
32 \\
32 \cdot 5 \\
35 \cdot 5 \\
36 \\
38 \\
39 \\
43 \\
43 \\
50 \\
51 \\
51 \\
54 \\
56 \\
56 \cdot 5 \\
58 \cdot 5 \\
59 \\
60 \cdot 5 \\
62 \\
66 \\
108 \\
129 \\
129\end{array}$ & $\begin{array}{l}1 \\
1 \\
1 \\
1 \\
1 \\
1 \\
1 \\
1 \\
1 \\
2 \\
2 \\
2 \\
2 \\
2 \\
2 \\
2 \\
2 \\
2 \\
3 \\
3 \\
3 \\
3 \\
3 \\
3 \\
3 \\
3 \\
3 \\
4 \\
4 \\
4 \\
4 \\
4 \\
4 \\
4 \\
4 \\
4 \\
5 \\
5 \\
5 \\
5 \\
5 \\
5 \\
5 \\
5\end{array}$ & $\begin{array}{l}1 \\
2 \\
1 \\
1 \\
2 \\
2 \\
1 \\
1 \\
1 \cdot 5 \\
1 \cdot 5 \\
2 \cdot 5 \\
1 \\
2 \\
1 \cdot 5 \\
2 \cdot 5 \\
3 \\
5 \\
2 \cdot 2 \\
5 \\
2 \\
2 \\
4 \\
4 \\
4 \\
4 \\
3 \cdot 5 \\
4 \cdot 5 \\
3 \\
3 \\
4 \\
3 \cdot 5 \\
5 \\
4 \\
2 \\
5 \\
5 \\
4 \\
4 \\
4 \cdot 5 \\
5 \\
5 \\
4 \cdot 5 \\
5 \\
5 \\
5 \\
\end{array}$ \\
\hline
\end{tabular}

$r=0.78 \mathrm{P}<0.001$

Prevalences per 100000 are averaged from Leibowitz and Alter (1973) except for Senegal and the Netherlands Antilles, from Kurtzk (1975); and SE Finland, from Wikstrom and Palo (1975).

tDental categories from McPhail and Grainger (1969), and Barmes and Infirri (1977).

The dental data in Table 4 are presented in terms of the proportion of edentulous individuals in the age group 55 to 64 , in various regions. The data were obtained from national dental surveys in England and Wales (Gray et al., 1970); Scotland (Todd and Whitworth, 1974); the United States of America (National Center for Health Statistics, 1971); Iceland (Dunbar et al., 1968); and Northern Ireland (Sheiham and Dimmer, 1971). The corresponding
MS prevalences were averaged from Tables 6.1 and 7.2 in Leibowitz and Alter (1973) except for the prevalence in the Scottish islands of Shetland, Orkney, Lewis, and Skye. This was averaged from Sutherland (1956).

Table $4 M S$ and edentulousness in temperate countries

\begin{tabular}{lll}
\hline Area & $\begin{array}{c}\text { MS* } \\
\text { prevalence }\end{array}$ & $\begin{array}{c}\% \text { edentuloust } \\
\text { ages 55-64 }\end{array}$ \\
\hline United States & 36 & 38 \\
England and Wales & 50 & 60 \\
Iceland & 51 & 63 \\
Scotland (mainland) & 62 & 78 \\
Northern lreland & 66 & 81 \\
Scotland (islands) & 66 & 80 \\
\hline & \\
r = 0.99 P<0.001 & \\
*Prevalences per 100 000 are averaged from Tables 6.1 and 7.2 in \\
Leibowitz and Alter (1973) \\
†Figures from national dental surveys in the US (National Center for \\
Health Statistics, 1971); England and Wales (Gray et al.; 1970); \\
Iceland (Dunbar et al., 1968); Scotland (Todd and Whitworth, \\
1974); and a survey in Northern Ireland (Sheiham and Dimmer, \\
1971)
\end{tabular}

Results

Tables 1 to 4 show the similarity in geographical distributions of MS and dental caries.

\section{AUSTRALIA}

The numbers of DMF teeth and the MS death rates in the Australian states are presented in Table 1. The DMF average ranges from 17.5 in Western Australia to 21.98 in Tasmania. Although the differences in DMF teeth among states are relatively small, analysis of the data (Dunning, 1953) showed seven statistically significant differences: Western Australia differs significantly from both Queensland and Victoria, and Tasmania differs significantly from all the other states. It therefore seems reasonable to attach some significance to the geographical variation in caries rates in Australia. Comparison of DMF teeth with the MS death rates results in a correlation coefficient of 0.97 , and the probability of a chance occurrence is less than 0.002 . This represents a nearly perfect linear relationship between dental disease rates and MS death rates.

The proportion of dentists in the various states is presented in order to determine whether DMF teeth are influenced significantly by the level of dental care. It has been suggested that the DMF index may vary directly with the level of care, because dentists tend to fill undecayed teeth as a prophylactic measure (Jackson, 1974). In Australia, the DMF figures do not show a positive correlation with the prevalence of dentists, but rather a slight negative correlation. In fact, levels of dental care were relatively uniform because free treatment was made available to schoolchildren in all the states at least as early as 
1933 (Official Yearbook, 1940). The variation in DMF teeth in Australia thus seems to represent actual variation in disease rates.

\section{UNITED STATES OF AMERICA}

Table 2 presents the dental health ranks for the US from 1918 to 1943 , and the MS death rates from 1946 to 1967. Although the dental ranks are based on studies of males, the figures are representative for both sexes, since geographical variations in dental caries in the US are similar for both sexes (Kelly, 1974). Comparing dental health ranks with MS ranks results in a highly significant correlation coefficient of $0.55(P<0.001)$. The variation in dental health ranks cannot be explained simply be variations in levels of dental care among States, because two of the three dental surveys were based solely on decayed and missing teeth. So the dental health ranks are fair measures of actual disease rates, as assumed by Dunning (1953). More recent surveys in the US have found similar geographical patterns in dental caries (Ludwig and Bibby, 1969; Kelly, 1974).

\section{WORLD}

The prevalences of MS in 45 countries or geographical areas are ranked in order of increasing prevalence in Table 3, with the corresponding index of dental health for each entry. A correlation coefficient of $0.78(P<0.001)$ points to the existence of a close relationship in worldwide MS and dental disease rates. It can be seen that dental caries rates are low in tropical countries and generally increase with north and south latitudes, except for Japan, which has low rates.

Technical advance among countries usually varies with latitude, so the way in which this factor may indirectly influence variations in dental caries has to be considered. Specifically, it might be postulated that the DMF teeth index varies directly with levels of dental care or survey methodology. This postulate was already ruled out for the last two correlations. A WHO dental epidemiologist (Barmes, 1977) has stated that technically advanced countries do experience high tooth mortality, and this is hardly affected by widespread dental care. This fact can be seen independently of the DMF index simply by considering the proportion of individuals in various countries with no caries whatever. It will also be seen below that the proportion of caries-free adolescents ranges from more than $60 \%$ in African countries (Enwonwu, 1974; Retief et al., 1975) to $7 \%$ in the United States of America (Kelly, 1974) and less than $3 \%$ in England (Todd, 1975). The worldwide variation in DMF teeth therefore seems to be directly related to actual variation in rates of disease. Nevertheless, it is still possible that the rates of dental disease are influenced by factors related to technical advance, such as diet, and some of these will be discussed.

Using a scale of one to five for correlating the data means that the extreme ends of the data are not seen, so it is useful to examine actual figures from certain countries where data are available. An extremely low or zero rate of MS was reported among the Eskimos in the area around Anchorage, Alaska, during the period 1950 to 1963 (Kurtzke, 1975). This correlates well with the very low rate of caries found among Eskimos from the same area in a survey in 1960 (Russell et al., 1961). These data were not included in the list, however, because caries rates among certain groups of urbanised Eskimos have increased in recent decades (Curzon and Curzon, 1970; McPhail et al., 1972). Another important test case not included in the correlation is that of the 15 million Bantus of South Africa, who are possibly unique in the total absence among them of any reported MS cases (Dean, 1967). Dental surveys in 1937 (Staz, 1937) and more recently (Retief et al., 1975) have found extremely low rates of caries among this population. Sixty per cent of rural Bantus aged 16 to 17 years were entirely free from caries, and $33 \%$ of urban Bantus. The average DMF for both rural and urban Bantus was 1.7. These figures are among the lowest found anywhere in the world. In the United States of America only 7\% of those aged 16 to 17 years are caries free, and the DMF is 8.0 (Kelly, 1974). In England the caries-free proportion of those aged 16 to 17 years is $3 \%$ (Todd, 1975), and the average DMF in this age group ranges from $11 \cdot 5$ to $13 \cdot 3$ (Jackson, 1974).

By contrast with the Bantus, the coloured and Indian peoples of South Africa experience moderate rates of dental disease. The caries-free proportion of 16- to 17 -year-old coloureds is only $7.5 \%$, and DMF teeth average 5.8. The figures for South African Indians are similar, and it has been suggested that increasing urbanisation, accompanied by dietary changes, has led to dental deterioration among these groups in the last few decades (Retief et al., 1975). The first report on MS among non-whites in South Africa has recently appeared (Ames and Louw, 1977); the cases included seven coloured people and one Indian. The appearance of MS for the first time among these racial groups is interesting in view of their declining dental health. Among the English-speaking white population, the prevalence of MS was 11 per 100000 in a survey in 1960 (Kurtzke, 1975), but since 1964 there have been well documented annual increases in new cases of MS among the whites (Bird and Satoyoshi, 1975), and current prevalence is certainly higher. An increasing frequency of dental caries in this population was noted 20 years before 
the increase in MS (Ockerse, 1944). Among Englishspeaking whites, DMF teeth at present average 10.0 (Retief et al., 1975). This is the highest rate in South Africa, although somewhat lower than the corresponding averages of 11.5 to 13.3 found in England.

The highest frequency of MS is found in Northern Ireland and the Scottish islands, and these areas of the world also rank highest in dental disease. Table 4 presents data compiled from national dental health surveys in Scotland, England, the United States of America, Iceland, and Northern Ireland. The data show the percentages of edentulous individuals in the age group 55 to 64 (a measure of severe and prolonged dental disease). When this variable is compared with MS prevalences, the result is an extremely high coefficient of 0.99 $(P<0.001)$. In Northern Ireland and the Scottish islands $80 \%$ of individuals aged 55 to 64 have no natural teeth. This is the highest rate of tooth loss reported in the world. Edentulousness is not simply a problem of old age in these countries, since in Scotland $15 \%$ of all individuals become edentulous before the age of 30 (Todd and Whitworth, 1974).

It should be noted that, at least in northern Scotland and England, dental disease was not always a severe problem; according to some authors, advancing civilisation, accompanied by changes in diet, has caused the problem (Hardwick, 1960; Lunt, 1974; Corbett and Moore, 1976). A modern illustration of this point is found in the Scottish Island of Lewis. A study by the British Medical Research Council of dental health there in 1938 (King, 1940), found that rates of caries were very low, especially among children in rural areas. For example, $31 \%$ of rural adolescents were free of caries, but only $12 \%$ of urban adolescents. A follow-up survey in 1968 by the same research council (Hargreaves, 1972) reported no caries-free adolescents, extremely high rates of caries, and no difference between urban and rural rates. Similarly dramatic increases in dental decay after the second world war have been documented in diverse regions of the world where diets have become increasingly 'Westernised' (Walker, 1975; Hartles and Leach, 1977). In Lewis, dietary surveys made in conjunction with dental surveys (Cathcart et al.,
1940; Hargreaves, 1972) showed that certain changes in diet are believed to be responsible for the increase in dental caries. The major change was the substitution of meat for fish.

Geography apart, several other epidemiological characteristics of MS resemble those of caries as listed in Table 5. These are discussed below.

\section{RACE}

Blacks have been shown to have a reduced risk of MS, irrespective of geography. The case/control ratio obtained in a US Army study suggests that the risk of MS for white males is 2.5 times the risk for black males (Kurtzke, 1975). National dental surveys in the United States of America have clearly demonstrated a reduced risk for dental caries among blacks in various age groups, irrespective of geography and socioeconomic differences (Kelly 1974; Rowe et al., 1976). For example, in the age group 20-24 years, whites in the United States of America have 1.8 times as many DMF teeth as blacks. Several smaller scale dental surveys have reached similar conclusions (Hyde, 1944; Szwejda, 1962; Miller and Chrietzberg, 1962; Jong, 1968; Littleton et al., 1970) although some reports have appeared of exceptional communities in the United States of America where blacks have as much or more caries than whites (Creighton, 1969; Bagramian and Russell, 1971; Infante and Owen, 1975). In England, blacks have a lower caries rate than whites. A study of adolescent girls attending a London school showed that the Negro girls had significantly less caries than the European girls (Downer, 1970). Negro schoolchildren in Liverpool also have significantly less caries than their white classmates (Varley and Goose, 1971). As was mentioned earlier, the coloured and Indian peoples, and especially the Bantus, in South Africa have less caries than whites (Retief et al., 1975). Black Nigerians, including those in the higher socioeconomic classes, have significantly reduced caries rates compared with European residents of Nigeria (Enwonwu, 1974; Akpabio, 1967). Thus, there is a vast body of evidence in support of the idea that blacks experience significantly fewer caries than whites; the question whether this

Table 5 Epidemiological comparison of $M S$ and dental caries

\begin{tabular}{lll}
\hline Characteristic* & Multiple sclerosis & Dental caries \\
\hline Geographic variation & Increases with N. latitude & Increases with N. latitude \\
& Increases with S. latitude & Increases with S. latitude \\
Low in tropics & Much lower in immigrants \\
Asian immigrants vs native British & Low in tropics & More frequent in higher class \\
Social class in US & Much lower in immigrants & No difference \\
Urban vs rural rates & More frequent in higher class & None demonstrated \\
Seasonal incidence & No difference & Much more prevalent in whites \\
Racial diference & None demonstrated & Higher in females \\
Sex distribution & Much more prevalent in whites & Increased risk \\
Effect of pregnancy and lactation & Higher in females & Increased risk
\end{tabular}

*For sources see text 
difference is genetic or cultural cannot be answered with the information at present available.

A study of Orientals living in California and Washington (Detels, et al., 1972) indicated that this group had a much lower risk of MS than Caucasians. Parallel results are found for dental disease. Chinese residents of the United States of America were found to have the lowest rate of DMF teeth of any ethnic group examined in a large military study (Hyde, 1944); blacks had a slightly higher rate. The highest DMF teeth rates were found among those of English or Irish extraction. Chinese adult immigrants to Britain have excellent teeth compared with native British of the same ages (Goose and Lee, 1976), but children born to these immigrants have as many DMF teeth as native English children, or more. Parallels are found in MS migration studies.Asian immigrants to Britain were found to have a reduced risk of MS compared with European British (Dean et al., 1977). A more detailed study in Israel showed that Afro-Asians who immigrated to Israel after the age of five had a lower risk of MS than European immigrants of comparable ages, but Afro-Asians who immigrated before the age of five acquired a risk as high as, or higher than, the Europeans (Alter, 1977). The migration studies seem to suggest that similar racial and environmental factors influence both MS and dental caries.

\section{SEX}

MS is generally more common in women than in men (Leibowitz and Alter, 1973), and dental caries are more prevalent in women of all age groups than in men, according to national surveys in the United States of America (Kelly, 1974); Iceland (Dunbar et al., 1968); England (Gray et al., 1970); Scotland (Todd and Whitworth, 1974); Germany (Shirmer et al., 1975); and Polynesia (Beck and Ludwig, 1966). It has been suggested that very young girls have more caries than boys because of earlier tooth eruption in girls (Carr, 1962), but this does not explain the marked differences in caries between older women and men.

Pregnancy and lactation increase the risk of MS (Schapira et al., 1966) and of dental caries too (Böttscher et al., 1970; Chapman et al., 1971; Orosz et al., 1975).

\section{SOCIOECONOMIC FACTORS}

Recent reviews (Leibowitz and Alter, 1973; Acheson, 1977) have pointed out that studies from various countries on socioeconomic factors associated with MS disagree substantially, so any conclusions drawn must be relative to the country and the methodology. Two cases are considered here for which there are directly comparable data for both MS and dental disease. In the United States of America, a study of ex-servicemen (Beebe et al., 1967) indicated that the risk of MS was higher for the higher socioeconomic classes. A dental survey of 67000 men selected for military service in the United States of America (Hyde, 1944) also found significantly more caries among the highest socioeconomic classes compared with the lowest. This socioeconomic gradient in dental disease was confirmed in recent national surveys (National Center for Health Statistics, 1967; Rowe et al., 1972).

MS in Northern Ireland is significantly more frequent among agricultural workers compared with employers, managers, and professionals (Acheson, 1977), apparently opposite to the trend in the United States. Dental disease follows the MS pattern in Northern Ireland; a recent survey found significantly more dental caries among manual compared with non-manual workers (Sheiham and Dimmer, 1971). In England there is controversy about the relation of social class to MS risk (Kurland et al., 1965; Campbell, 1971); hence no firm comparison with dental caries can be made.

\section{Discussion}

Dental disease appears to correlate with MS to at least the same extent as poliomyelitis, previously proposed as the epidemiological model for MS (Poskanzer et al., 1963). In some respects, dental disease may be a better model for MS, because polio was epidemic in the tropics and parts of Japan, as well as Alaska and the Arctic (Leibowitz and Alter, 1973). The fact that polio, a disease of viral origin, and dental caries, the origin of which is largely dietary, can both correlate with MS illustrates very clearly the limitations of epidemiological correlation. Specifically, it must be remembered that a correlation of MS with either polio or dental caries does not imply a direct or meaningful relationship. The search for a MS virus has so far proved fruitless; it is interesting to consider the possibility that the aetiologies of dental caries and MS are similar.

Because MS has been shown to correlate well with both dental caries and cancer of the colon (Wolfgram, 1975), the aetiological factors that the three diseases may share in common can be explored. The factors involved in dental caries are not completely understood, and will be mentioned only briefly here. Refined carbohydrates, especially sucrose, are believed to be primary sources of decay, and fluoride may be a primary protective agent. Other possible cariogenic dietary factors include excesses of fat (Mandel, 1970), and the minerals $\mathrm{Cu}, \mathrm{Fe}, \mathrm{Zn}, \mathrm{Se}, \mathrm{Mn}$, and K (Helle, 1977; Hartles and Leach, 1977). Other protective factors may be vitamins $\mathrm{C}$ and $\mathrm{D}$ and the minerals $\mathrm{Ca}, \mathrm{Mg}$, Mo, $\mathrm{Va}, \mathrm{Sr}, \mathrm{B}$, and Li (Helle, 1977; Hartles and Leach, 1977). 
In order to choose the factors relevant to the present study, it is of interest to examine the factors responsible for dental deterioration in the Isle of Lewis, previously mentioned. The dietary surveys there in 1937 and 1967, obtained through intensive family interviews, revealed that per caput consumption of both refined carbohydrates and sugar actually declined slightly in the later survey. The most significant change in the diet was a substitution of meat for fish, resulting in a large increase in fat consumption, and decreases in consumption of vitamin $D$ and the trace minerals present in fish. A similar dietary change away from fish apparently occurred in the nearby Shetland Islands during this century (Cluness, 1951), where there has been a sharp, linear increase in MS since 1954 (Poskanzer et al., 1976). Fish would be a primary source of vitamin D in these islands, where sunshine is rare. An increase in fish consumption, conversely, has been implicated as one of the factors responsible for the decline in caries among children in most European countries during the war (Mandel, 1970). Evidence from Northern Europe thus appears to suggest that caries increase as the total fat intake increases, and as the fish intake declines.

A recent review of colon cancer (Cummings, 1978) indicated that, while dietary fibre may protect against the disease, the most important causative factors are excesses of dietary fat and animal protein. An epidemiological survey found that the incidence of cancer of the colon correlated more closely with total fat intake than with any other variable studied, including total consumption of animal products (Knox, 1977).

The possible relationship of MS to animal fat consumption, first suggested by Swank (1950), has recently been elaborated by Dick (1976) and Alter (1977). It is suggested by these authors that dietary excesses of certain fats may cause errors in the development of myelin, possibly very early in life, and these may render the myelin unstable or susceptible to attack. It has been proposed that a vitamin $\mathbf{D}$ deficiency early in life could also cause errors in myelin (Goldberg, 1974). Recent experiments on myelination in vitro support the latter proposal (Craelius et al., 1978).

The possibility that the close correlations found between MS and dental disease are due to chance is extremely unlikely, and it has been shown that MS prevalence varies with actual rates of dental disease and not simply with dental indices which are influenced by levels of dental care. Increases in the prevalence of dental caries both in South Africa and in the Scottish islands have been followed by increases in the prevalence of MS. Conceivably, the correlation may be due to factors unrelated to aetiology. It might be hypothesised, for example, that the higher intake of refined foods by more civilised peoples of higher latitudes accounts for their caries incidence, but not for MS. The results contradict this argument. It is unlikely that the variation in dental disease seen in Table 4 can be explained by differing intakes of refined foods among the regions. Also, the argument cannot easily explain the south to north increases in caries in the United States of America and in England (Gray et al., 1970). In fact, a recent dietary and dental survey of 457 children in Canada showed absolutely no relationship between dental caries and intake of refined foods (Richardson et al., 1977). This lack of relationship is also seen in the example of the Bantus, whose intake of refined carbohydrates has markedly increased in the last few decades, with virtually no increase in caries (Walker, 1975). Conversely, on the Isle of Lewis, consumption of refined carbohydrates declined slightly, at a time when caries rates increased (Hargreaves, 1972). There is no reason to believe, then, that the epidemiology of dental caries can be explained by differences in intake of refined foods. It is suggested that the possibly meaningful explanations of the correlation, such as fat intake, or vitamin $D$ deficiency, be further explored.

I thank Dr. Donald Kennedy for the use of facilities and for criticisms, and Dr. Nicki Ann Newby for helpful discussions. This work was supported in part by a Postdoctoral Award from the National Institute of Health, Bethesda, USA.

Reprints from William Craelius, Department of Biology, Lafayette College, Easton, Pennsylvania 18042, USA.

\section{References}

Acheson, E. D. (1961). Multiple sclerosis in British Commonwealth countries in the southern hemisphere. British Journal of Preventive and Social Medicine, 15, 118-125.

Acheson, E. D. (1977). Epidemiology of multiple sclerosis. British Medical Bulletin, 33(1), 9-14.

Acheson, E. D., Bachrach, C., and Wright, F. (1960). Some comments on the relationship of the distribution of multiple sclerosis to latitude, solar radiation, and other variables. Acta Psychiatrica et Neurologica Scandinavica, 35, 132-147.

Akpabio, S. P. (1967). The prevalence of dental caries in Nigerian populations. British Dental Journal, 124(1), 6.

Alter, M. (1977). Clues to the cause based upon the epidemiology of M.S. In Multiple Sclerosis. A Critical Conspectus. Edited by E. J. Field. University Park Press: Baltimore.

Ames, F. R., and Louw, S. (1977). Multiple sclerosis in coloured South Africans. Journal of Neurology, Neurosurgery and Psychiatry, 40, 729-735. 
Andrews, N. H. (1948). A study of the dental status of male and female personnel, Royal Australian Air Force. 1939-1945. Australian Journal of Dentistry, 52, 12-24.

Bagramian, R. A., and Russell, A. I. (1971). An epidemiologic study of dental caries in race and geographic area. Journal of Dental Research, 50, 1553-1556.

Barmes, D. E. (1977). World wide distribution and significance of oral diseases. International Dental Journal, 27(3), 270-272.

Barmes, D. E., and Infirri, J. S. (1977). WHO activities in oral epidemiology. Community Dentistry and Oral Epidemiology, 5, 22-29.

Beck, D. J., and Ludwig, T. G. (1966). Sex differences in dental disease in Polynesian peoples. New Zealand Dental Journal, 62, 279-291.

Beebe, G. W., Kurtzke, J. F., Kurland, L. T., Auth, T. L., and Nagler, B. (1967). Studies on the natural history of multiple sclerosis. 3. Epidemiological analysis of the army experiences in World War II. Neurology, 17, 1.

Bird, A. V., and Satoyoshi, E. (1975). Comparative epidemiological studies of multiple sclerosis in South Africa and Japan. Journal of Neurology, Neurosurgery and Psychiatry, 38, 911-918.

Blackberry, P. E. (1943). Intrastate geographical variations in dental caries rates. Journal of the American Dental Association, 30, 1241-1245.

Böttscher, V., Schnilewski, R., Schönberger, A., and Wöller, M. (1970). Studies on the intensity of caries and periodontal disease during pregnancy and lactation. Deutsche Gesundheitswesen, 25(39), 18521857.

Britten, R. H., and Perrott, G. S. J. (1941). Summary of physical findings on men drafted in the world war. Public Health Reports (Washington), 56, 41-62.

Campbell, A. M. G. (1971). Multiple sclerosis: occupation and social group at onset. Lancet, 2, 1095.

Carp, R. I., Merz, G. S., Merz, P. A., and Licursi, P. C. (1977). A multiple sclerosis associated virus: Past, present, and future. In Multiple Sclerosis: A Critical Conspectus. Edited by E. J. Field. University Park Press: Baltimore.

Carr, L. M. (1962). Eruption ages of permanent teeth. Australian Dental Journal, 7, 367-373.

Cathcart, E. P., Murray, A. M. T., and Beveridge, J. B. (1940). Medical Research Council Special Report Series No. 242. HMSO: London.

Chapman, P. J., McDonald, A. M., Stoddart, R. J., and Mackay, E. V. (1971). Dental health of pregnant women. Medical Journal of Australia, 2(22), 1117-1120.

Cluness, A. T. (1951). The Shetland Isles, pp. 144-148. Hale: London.

Corbett, M. E., and Moore, W. J. (1976). Distribution of dental caries in ancient British populations. IV. The 19th Century. Caries Research, 10, 401-414.

Craelius, W., Newby, N. A., and Thomas, F. C. (1978). Central myelination in vitro: effect of reduced calcium and magnesium. Neuroscience Abstracts. In press.
Creighton, W. E. (1969). Dental caries experience of Negro and Caucasian children in Portland, Oregon. Journal of Dentistry for Children, 36, 65-69.

Cummings, J. H. (1978). Dietary fibre and caloric function. Proceedings of the Royal Society of Medicine, 71, 81-84.

Curzon, M. E. J., and Curzon, J. A. (1970). Dental caries in Eskimo children of the Leewatin district in the Northwest Territories. Journal of the Canadian Dental Association, 36(9), 342-345.

Dean, G. (1967). Annual incidence, prevalence, and mortality of multiple sclerosis in white South Africanborn and in white immigrants to South Africa. British Medical Journal, 2, 724-730.

Dean, G., Brady, R., McLoughlin, H., Elian, M., and Adelstein, A. (1977). Motor neurone disease and multiple sclerosis among immigrants to Britain.. British Journal of Preventive and Social Medicine, 31, 141-147.

Detels, R., Brady, J. A., and Edgar, A. H. (1972). Multiple sclerosis among American, Japanese, and Chinese immigrants to California and Washington. Journal of Chronic Diseases, 25, 3.

Dick, G. (1976). The aetiology of multiple sclerosis. Proceedings of the Royal Society of Medicine, 69, 611-615.

Downer, M. C. (1970). Dental caries and periodontal disease in girls of different ethnic groups. British Dental Journal, 129, 379-385.

Dunbar, J. B., Moller, P., and Wolff, A. E. (1968). A survey of dental caries in Iceland. Archives of Oral Biology, 13, 571-581.

Dunning, J. M. (1953). The influence of latitude and distance from seacoast on dental disease. Journal of Dental Research, 32, 811-829.

East, B. R. (1939). Mean annual hours of sunshine and incidence of dental caries. American Journal of Public Health, 28, 777-780.

Enwonwu, C. (1974). Socioeconomic factors in dental caries prevalence and frequency in Nigerians. Caries Research, 8, 155-171.

Ferguson, R. A. (1935). Some observations on diet and dental disease. Journal of the American Dental Association, 22, 392-401.

Firnhaber, W., and Orth, H. (1977). The pathogenetic importance of the affection and of the theory of MS patients' teeth in comparison to those of epileptics. Journal of Neurology, 215, 141-149.

Fulton, J. T. (1951). Experiment in Dental Care. WHO Monograph No. 4. WHO: Geneva.

Goldberg, P. (1974). Multiple sclerosis: vitamin D and calcium as environmental determinants of prevention. Part I. Sunlight, dietary factors, and epidemiology. International Journal of Environmental Studies, 6, 19-27.

Goose, D. H., and Lee, G. T. (1976). Prevalence of dental caries of Chinese in Liverpool. Annals of Human Biology, 3(2), 187-188.

Gray, P. G., Todd, J. E., Stork, G. L., and Bulman, J. S. (1970). Adult Dental Health in England and Wales. HMSO: London. 
Hardwick, J. L. (1960). The incidence and distribution of caries throughout the ages in relation to the Englishman's diet. British Dental Journal, 108, 9-17.

Hargreaves, J. A. (1972). Changes in diet and dental health of children living in the Scottish Island of Lewis. Caries Research, 6, 355-376.

Hartles, R. L., and Leach, S. A. (1977). Effect of diet on dental caries. British Medical Bulletin, 31(2), 127-141.

Helle, A. (1977). Comparison of minerals of drinking water, serum, stimulated saliva and deciduous teeth of healthy children and caries status. Proceedings of the Finnish Dental Society, 73, Supplement No. 2, 7-14.

Hess, A. F. (1929). Rickets, Osteomalacia and Tetany. Lea and Febiger: Philadelphia.

Hyde, R. W. (1944). Socioeconomic aspects of dental caries. New England Journal of Medciine, 230, 506-510.

Infante, P. F., and Owen, G. M. (1975). Dental caries and level of treatment for schoolchildren by geographical region, socioeconomic status, race, and size of community. Journal of Public Health and Dentistry, 35, 19-27.

Jackson, D. (1974). Caries experienced in English children and young adults during the years 1947-1972. British Dental Journal, 137, 91-98.

Johnson, R. T. (1975). Virological data supporting the viral hypothesis in multiple sclerosis. In Multiple Sclerosis Research. HMSO: London.

Jong, A. (1968). Racial differences in dental health status of preschool children. Journal of the Massachusetts Dental Society, 17(1), 29-33.

Kelly, J. E. (1974). Decayed, Missing and Filled Teeth Among Youths 12-17 Years, US. Public Health Service Publication, Series 11, No. 144. US Department of Health, Education and Welfare: Washington DC.

King, J. D. (1940). Dental Disease in the Isle of Lewis. Special Report Series No. 241. HMSO: London.

Knox, E. G. (1977). Foods and diseases. British Journal of Preventive and Social Medicine, 31, 71-80.

Kurland, L. T., and Reed, D. (1964). Geographic and climatic aspects of multiple sclerosis. American Journal of Public Health, 54(4), 588-597.

Kurland, L. T., Stazio, A., and Reed, D. (1965). An appraisal of population studies of multiple sclerosis. Annals of the New York Academy of Sciences, 122, 520-541.

Kurtzke, J. F. (1975). A reassessment of the distribution of multiple sclerosis. Part I. Acta Psychiatrica et Neurologica Scandinavica, 51, 110-136.

Kurtzke, J. F. (1977). Geography in multiple sclerosis. Journal of Neurology, 215, 1-26.

Landsberg, C. E., Lippman, H. P., Affen, Kh., and Troll, C. (1965). World Maps of Climatology, second edition. Springer: Berlin.

Leibowitz, U., and Alter, M. (1973). Multiple Sclerosis: Clues to its Cause. North Holland: Amsterdam.

Leibowitz, U., Kahana, E., and Alter, M. (1973). The changing frequency of multiple sclerosis in Israel. Archives of Neurology, 7, 253.

Leibowtiz, U., Sharon, D., and Alter, M. (1967). Geographical considerations in multiple sclerosis. Brain, 90, 871-885.
Limburg, C. (1950). The geographic distribution of multiple sclerosis and its estimated prevalence in the US. In Multiple Sclerosis and the Demyelinating Diseases. Williams and Wilkins: Baltimore.

Littleton, N. W., Kakehoshi, S., and Fitzgerald, R. J. (1970). Study of differences in the occurrence of dental caries in Caucasian and Negro children. Journal of Dental Research, 49, 742-751.

Ludwig, T. G., and Bibby, B. G. (1969). Geographic variations in the prevalence of dental caries in the United States of America. Caries Research, 3, 32-43.

Lunt, D. A. (1974). The prevalence of dental caries in the permanent dentition of Scottish prehistoric and medieval populations. Archives of Oral Biology, 19, 431-437.

Mandel, I. D. (1970). Effect of dietary modifications on caries in humans. Journal of Dental Research, Supplement to No. 6, 1201-1211.

McAlpine, D., Lumsden, C. E., and Acheson, E. D. (1963). Multiple Sclerosis, p. 27. Williams and Wilkins: Baltimore.

McPhail, C. W. B. (1967). Geographic pathology of dental caries. MS thesis, University of Toronto.

McPhail, C. W. B., Curry, T. M., Hazelton, R. D., Paynter, K. J., and Williamson, R. G. (1972). The geographic pathology of dental disease in Canadian central arctic populations. Journal of the Canadian Dental Association, 38(8), 288-296.

McPhail, C. W. B., and Grainger, R. M. (1969). A mapping procedure for the geographical pathology of dental caries. International Dental Journal, 19, 380-392.

Mellanby, E. (1921). Experimental rickets. Special Report Series of the Medical Research Course, No. 61. HMSO: London.

Miller, S. L., and Chrietzberg, J. D. (1962). Caries experience among children in two fluoridated communities where the fluoride concentration was adequately miantained in only one. Journal of Public Health Dentistry, 22, 61-75.

Mills, C. A. (1937). Factors affecting the incidence of dental caries in population groups. Journal of Dental Research, 16(5), 417-430.

National Center for Health Statistics (1967). Decayed, Missing, and Filled Teeth in Adults: United States 1960-1962. Public Health Service Publication, Series 11, No. 23. US Department of Health, Education and Welfare: Washington DC.

National Center for Health Statistics (1971). Edentulous Persons, United States, 1971. Public Health Service Publication, Series 10, No. 89. US Department of Health, Education and Welfare: Washington DC.

Nizel, A. E., and Bibby, B. G. (1944). Geographic variations in caries prevalence in soldiers. Journal of the American Dental Association, 31, 1619-1626.

Ockerse, T. (1944). The incidence of dental caries amongst European schoolchildren in South Africa in age groups from 6 to 14 years. South African Dental Journal, 17, 166-168.

Official Yearbook of the Commonwealth of Australia (1940). No. 23. Commonwealth Bureau of Census and Statistics: Canberra. 
Official Yearbook of the Commonwealth of Australia (1946-47). No. 37. Commonwealth Bureau of Census and Statistics: Canberra.

Orosz, M., Rij'o, O., and B'an'oczy, J. (1975). Relationship between pregnancy and dental caries. Fogorvosi Szemle, 68(11), 327-332.

Palm, T. A. (1890). The geographical distribution and aetiology of rickets. Practitioner, 45, 321-340.

Poskanzer, D. C., Schapira, K., and Miller, H. (1963). Multiple sclerosis and poliomyelitis. Lancet, 2 , 917-921.

Poskanzer, D. C., Walker, A. M., Yonkondy, J., and Sheridan, J. L. (1976). Studies in the epidemiology of multiple sclerosis in the Shetland and Orkney Islands. Neurology, 26, 14-17.

Retief, D. H., Cleaton-Jones, P. E., and Walker, A. R. P. (1975). Dental caries and sugar intake in South African pupils of 16 to 17 years in four ethnic groups. British Dental Journal, 138, 463-469.

Rhodes, A. J. (1949). Poliomyelitis among Eskimos. Canadian Journal of Public Health, 40, 440-442.

Richardson, A. S., Boyd, M. A., and Conry, R. F. (1977). A correlation study of diet, oral hygiene and dental caries in 457 Canadian children. Community Dentistry and Oral Epidemiology, 5, 227-230.

Rowe, N. H., Garn, S. M., Clark, D. C., and Guire, K. E. (1976). The effect of age, sex, race, and economic status on the dental caries experience of the permanent dentition. Pediatrics, 57, 457-463.

Russell, A. L., Consolazio, C. F., and White, C. F. (1961). Dental caries and nutrition in Eskimo scouts of the Alaska National Guard. Journal of Dental Research, 40, 594-603.

Saunders, J. L. (1945). Dental caries: A study of regional variations in New Zealand. Transactions of the Royal Society of New Zealand, 75, 57-64.

Schapira, K., Poskanzer, D. C., Newell, D. J., and Miller, H. (1966). Marriage, pregnancy, and multiple sclerosis. Brain, 89, 419-429.

Shaw, J. H. (1970). Preeruptional effects of nutrition on teeth. Journal of Dental Research, Supplement No. 6, 1238-1250.

Sheiham, A., and Dimmer, A. (1971). A dental epidemiological survey of a Northern Ireland population: dental caries and periodontal findings. Journal of the Irish Dental Association, 17(5), 150-158.

Shirmer, I., Schneider, H. C., and Arnod, H. (1975). Stomatological morbidity study, Berlin, 1972. Stomatologie $D D R, 25,739-742$.

Staz, J. (1937). Dental caries in South Africa. The South African Journal of Medical Sciences, Supplement No. 3, $1-58$.

Sutherland, J. M. (1956). Observations on the prevalence of multiple sclerosis in northern Scotland. Brain, 79, 635-654.

Swank, R. L. (1950). Multiple sclerosis: a correlation of its incidence with dietary fat. American Journal of Medical Science, 220, 421-430.

Symington, G. P., and Mackay, I. R. (1978). Cell mediated immunity to measles virus in multiple sclerosis: correlation with disability. Neurology, 28, 109-112.

Szwejda, L. F. (1962). Dental caries experience by race and socioeconomic level after eleven years of water fluoridation in Charlotte, North Carolina. Journal of Public Health Dentistry, 22, 91-98.

Todd, J. E. (1975). Children's Dental Health in England and Wales. HMSO: London.

Todd, J. E., and Whitworth, A. (1974). Adult Dental Health in Scotland. HMSO: London.

Varley, T. F., and Goose, D. H. (1971). Dental caries in children of immigrants in Liverpool. British Dental Journal, 130, 27-29.

Visscher, B. R., Detels, R., Coulson, A. H., Malmgren, R. M., and Dudley, J. P. (1977). Latitude, migration, and the prevalence of multiple sclerosis. American Journal of Epidemiology, 106, 470-475.

Walker, A. R. S. (1975). Sugar intake and dental caries in pupils in four South African ethnic groups. South African Medical Journal, 49, 616-620.

Wilkstrom, J., and Palo, J. (1975). Studies on the clustering of multiple sclerosis in Finland. I. Comparison between the domiciles and places of birth in selected subpopulations. Acta Neurologica Scandinavica, 51, 85-98.

Wolfgram, F. (1975). Similar geographical distribution of multiple sclerosis and cancer of the colon. Acta Neurologica Scandanavica, 52, 294-302. 